Boletín de la Sociedad Geológica Mexicana

VOLUMEN 68, NÚM. 2, 2016, P. 231-246

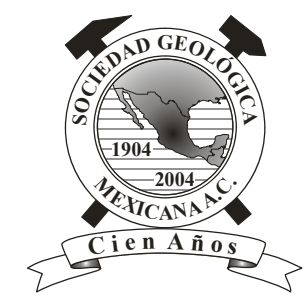

\title{
Eogeryon elegius n. gen. and n. sp. (Decapoda: Eubrachyura: Portunoidea), one of the oldest modern crabs from late Cenomanian of the Iberian Peninsula
}

\author{
Àlex Ossó ${ }^{1}$ \\ ${ }^{1}$ J.V. Foix, $12 \mathrm{H}, 1 \mathrm{er}-1^{\mathrm{a}}$, Tarragona, Catalonia \\ *aosso@comt.cat
}

\begin{abstract}
A new Heterotremata (Eubrachyura) decapod from the late Cenomanian of Condemios de Arriba (Guadalajara, Spain) is described. The new taxon has affinities with the basal portunoids and their features suggest placement within the Portunoidea. Comparisons with all the currently known Cretaceous Eubrachyura taxa demonstrates how Eogeryon elegius is an advanced crab in spite of its Cenomanian origins, suggesting that it evolved from ancestors previously unknown according to the current fossil record. As a result of those comparisons, a new family, Eogeryonidae, within Portunoidea, is proposed to accommodate the new genus and species. In addition, Eogeryon elegius is also compared with early Eocene and extant related taxa, with emphasis on the non-swimming portunoid family Geryonidae. Eogeryon elegius appears to be an ancestor of most derived forms of Portunoidea, suggesting that the evolution of Eubrachyura must have occurred at least during the Early Cretaceous.
\end{abstract}

Keywords: Crustacea, Brachyura, Heterotremata, Geryonidae, Cretaceous, Spain.

\section{Resumen}

Se describe un nuevo decápodo Heterotremata (Eubrachyura) procedente del Cenomaniano tardio de Condemios de Arriba (Guadalajara, España). Las afinidades con portunoideos basales que presenta el nuevo taxón, sugieren que su ubicación en Portunoidea es apropiada. Las comparaciones con todos los Eubrachyura del Cretácico actualmente conocidos, muestran que Eogeryon elegius es un cangrejo avanzado, a pesar de sus orígenes cenomanianos, lo que sugiere que evolucionó de ancestros mucho antes de lo que se podia prever a la vista del actual registro fósil. Como resultado de esas comparaciones, se propone una nueva familia, Eogeryonidae, incluida en Portunoidea, para acomodar el nuevo género y especie. Eogeryon elegius se compara, además, con taxones del Eoceno temprano y también actuales, con especial énfasis con la familia de portunoideos no nadadores Geryonidae. Eogeryon elegius podría ser un ancestro de formas más derivadas de Portunoidea, sugiriendo así, que la evolución de los Eubrachyura ocurrió, al menos durante el Cretácico temprano

Palabras clave: Crustacea, Brachyura, Heterotremata, Geryonidae, Cretácico, España. 


\section{Introduction}

The discovery of Eogeryon elegius n. gen., n. sp. in the late Cenomanian strata is paramount. The well-preserved ventral features leave no doubt about their belonging to Heterotremata (Eubrachyura). The general aspect, flattened body plan, sternum, abdomen and heterodontic right chela are attributes that correspond to a decapod with an advanced degree of carcinisation, notwithstanding its old age. This report indicates clearly that the Eubrachyura evolved earlier than we could foresee in view of the fossil record. Even though the fossil record shows that Eubrachyura are already present in the Early Cretaceous (Luque, 2015), for instance Telamonocarcinidae Larghi, 2004 (Dorippoidea) and Tepexicarcinidae Luque, 2015 (uncertain superfamily) (see Luque, 2015), they are considered primitive (Guinot et al., 2013). Therefore, it seems that Eogeryon elegius $\mathrm{n}$. gen., n. sp. evolved from more advanced Early Cretaceous forms than the aforementioned families. Comparisons with all the known eubrachyuran Cretaceous taxa show how Eogeryon elegius n. gen., n. sp. differs from many of those taxa, as is explained below. However, some affinities are found with its coeval Marocarcinus pasinii Guinot, De Angeli and Garassino, 2008, and also with other younger taxa such as genera and species belonging to the portunoid families Carcineretidae Beurlen, 1930 and Longusorbiidae Karasawa, Schweitzer and Feldmann, 2008, and with the portunoid-like Styracocarcinus meridionalis (Secrétan, 1961). Affinity of Eogeryon elegius n. gen., n. sp. with Portunoidea Rafinesque, 1815, appears to be evident, and their dorsal characters and chela fit well with the diagnosis provided for this superfamily by Karasawa et al. (2008) and Spiridonov et al. (2014). Regarding their portunoid affinities, it is noteworthy that the fullness of the typical ventral features of the most derived portunoids, for instance the Portunidae Rafinesque, 1815, were not completely acquired, according to the fossil record, until the middlelate Eocene. Therefore, in principle, it cannot be expected to find entirely portunid ventral structures in Cretaceous and Paleocene portunoid specimens. Particularly, the general features, both dorsal and ventral of Eogeryon elegius n. gen., n. sp. recall those of the non-swimming portunoids Geryonidae Colosi, 1923, considered the most basal family of Portunoidea (Karasawa et al., 2008; Schubart and Reuschel, 2009; Spiridonov et al., 2014). In this sense, some early Eocene species of Litoricola Woodward, 1873, formerly referred to Coeloma A. MilneEdwards, 1865, and probably related with Geryonidae, show affinities with Eogeryon elegius n. gen., n. sp. and they may be considered as intermediate forms between Eogeryon elegius n. gen., n. sp. and the extant Geryonidae. However the differences found amongst Eogeryon elegius n. gen., n. sp. and the above-mentioned taxa, and the time difference between them, warrants the proposal of a new family, within Portunoidea, to accommodate the new taxon.
Eogeryon elegius n. gen., n. sp. appears to be an ancestor of the most derived forms of Portunoidea. Portunoidea are the most represented Eubrachyura group during the Middle and Late Cretaceous. They successfully surpassed the K/P event, being at the present time one of the most diverse and species-rich groups of known eubrachyuran.

\section{Locality and geological setting}

Specimens of Eogeryon elegius n. gen., n. sp. were recovered from outcrops near the village of Condemios de Arriba (Northern Guadalajara Province, Spain) (Figure 1). The Condemios area is located in the Central Sector of the Inner Castilian Platform of the Iberian Trough, which connected from north to southeast the open waters of ProtoAtlantic Ocean and the Tethys Sea, through the Basque Basin and Levantine Basin (Barroso-Barcenilla et al., 2009, p. 139) (Figure 2). During the late Cenomanian-Turonian interval, increased subsidence and sea-level rise caused a broad and rapid transgression from the Proto-Atlantic that flooded the entire Iberian Trough, which was partially closed towards the Western Tethys in the south (Caus et al., 2009, p. 173-174, fig. 2). The Iberian Trough, bordered by the Hesperian Massif on the west and the Ebro Massif on the east, was temporally or permanently flooded by the Proto-Atlantic Ocean. According to Barroso-Barcenilla et al. (2009, p. 139, figure 1), during intervals of relatively high sea level the Iberian Trough extended from the Inner Castilian Platform to the southeast along the Levantine Platform, from which it directly received Tethyan influence. In the vicinity of Condemios de Arriba, a stratigraphic series of late Cenomanian-Turonian is well exposed. In the section, four lithostratigraphic units are recognised: the upper part of the Arenas de Utrillas Formation (Aguilar et al., 1971), Dolomías tableadas de Villa de Vés Formation (Vilas et al., 1982), Margas de Picofrentes Formation (Floquet et al., 1982) and Dolomías de la Ciudad Encantada Formation (Meléndez, 1971) (see Peyrot et al., 2012). The level bearing crab corresponds to the Villa de Vés Formation. This unit is frequently attributed to either the Utrillas Formation or as a mere member of the overlying Picofrentes Formation (Peyrot et al., 2012, p. 27; F. Barroso-Barcenilla, pers. com., 2014). The Villa de Vés Unit is characterized in this outcrop by a thin bed of sandy limestone that overlies the uppermost marine levels of the Utrillas Formation. It contains marine fauna of bivalves, gastropods, echinoids, and the ammonite Vascoceras gamai Choffat, 1898, whose Zone represents the upper part of the late Cenomanian, just below the Spathites (Jeanrogericeras) subconciliatus Zone which marks the end of Cenomanian. The Villa de Vés Unit is interpreted as a shallow marine platform of Tethyan affinity (Peyrot et al., 2012, p. 27) (Figure 3). 


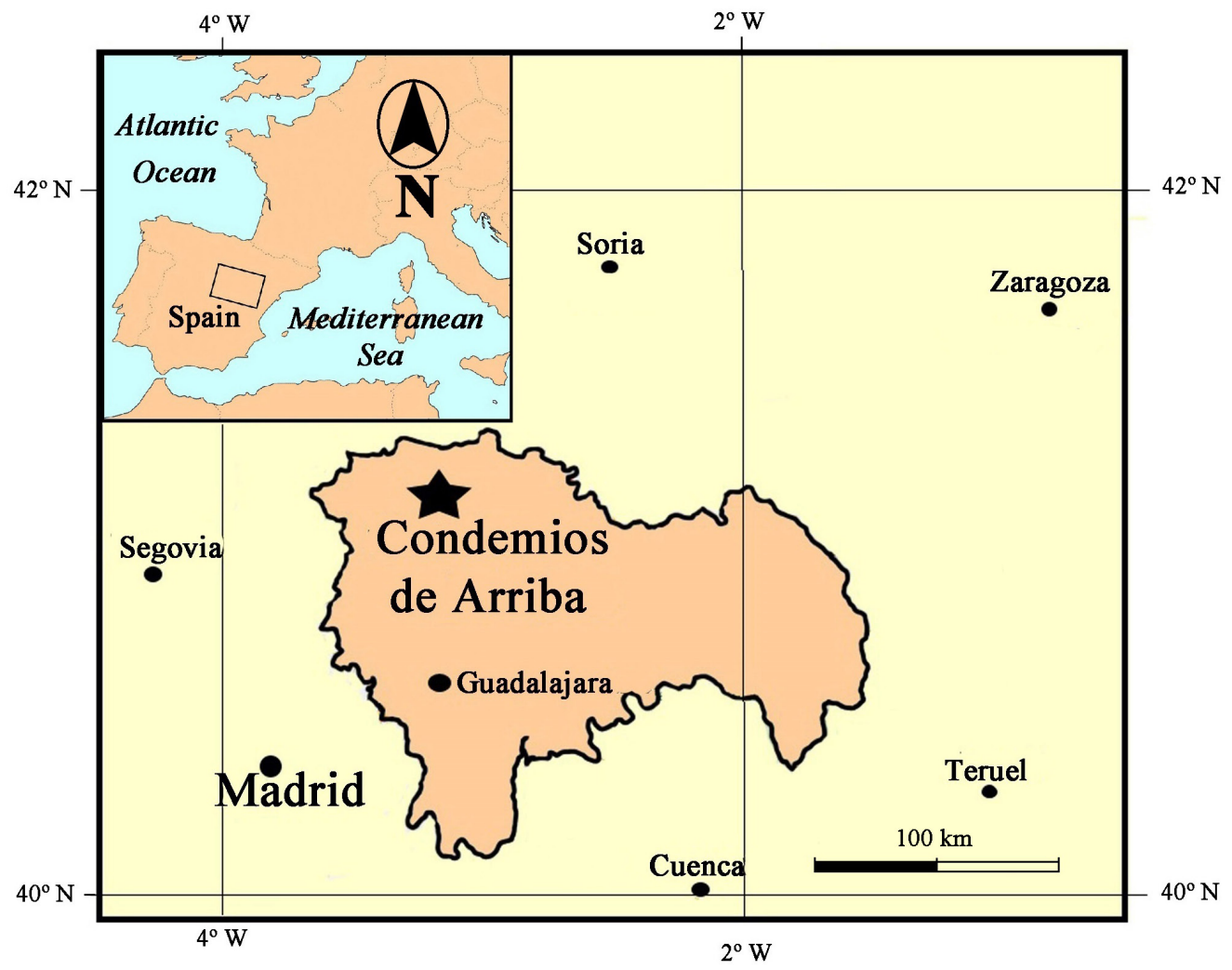

Figure 1. General map with location of type locality (star).

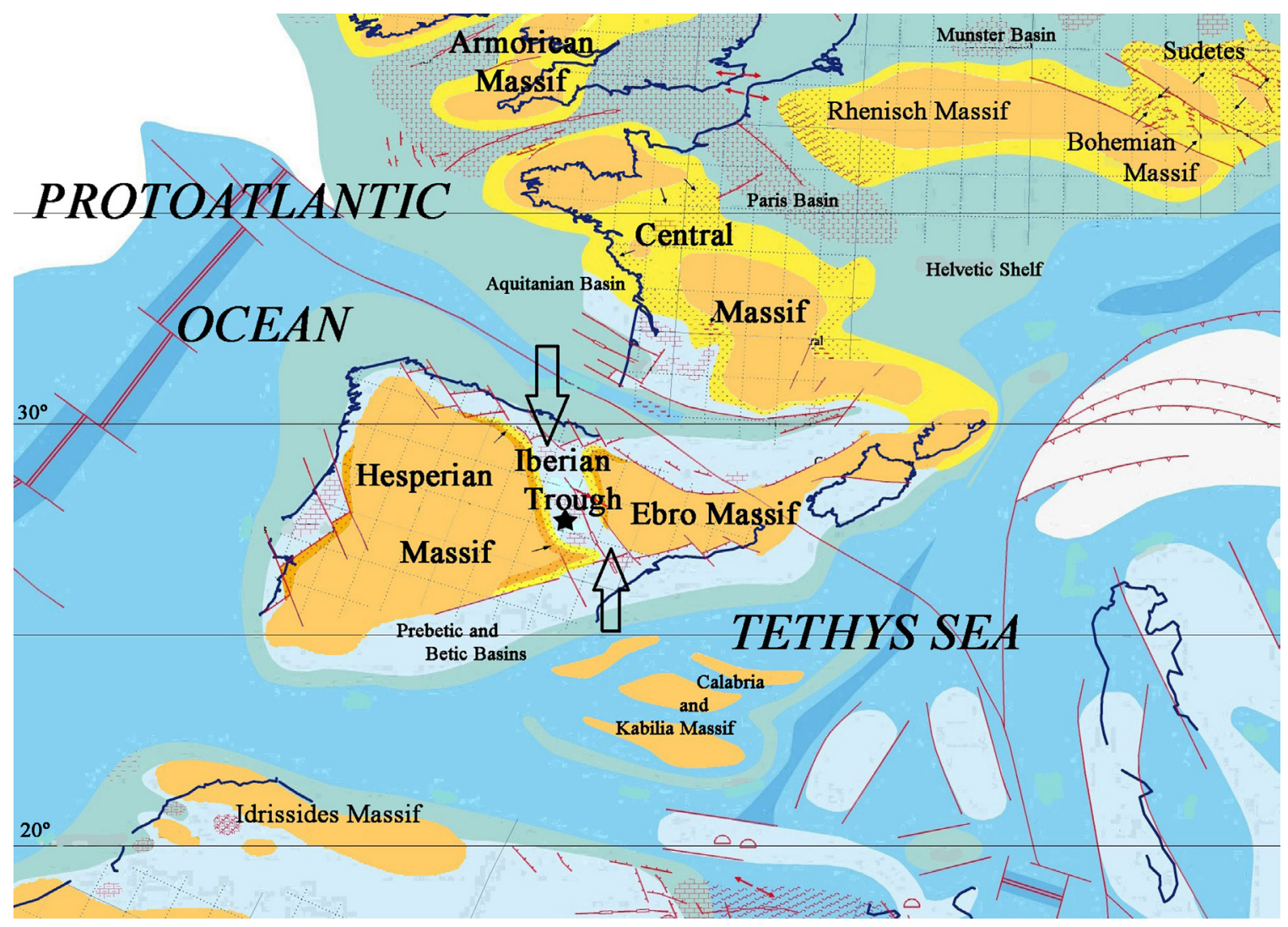

Figure 2. Palaeogeographic general situation of the Iberian Peninsula during the maximum transgression of the late Cenomanian-Early Turonian, with approximate situation of the outcrop (star). Modified from Philip and Floquet (2000) according to F. Barroso-Barcenilla et al. (2011). 


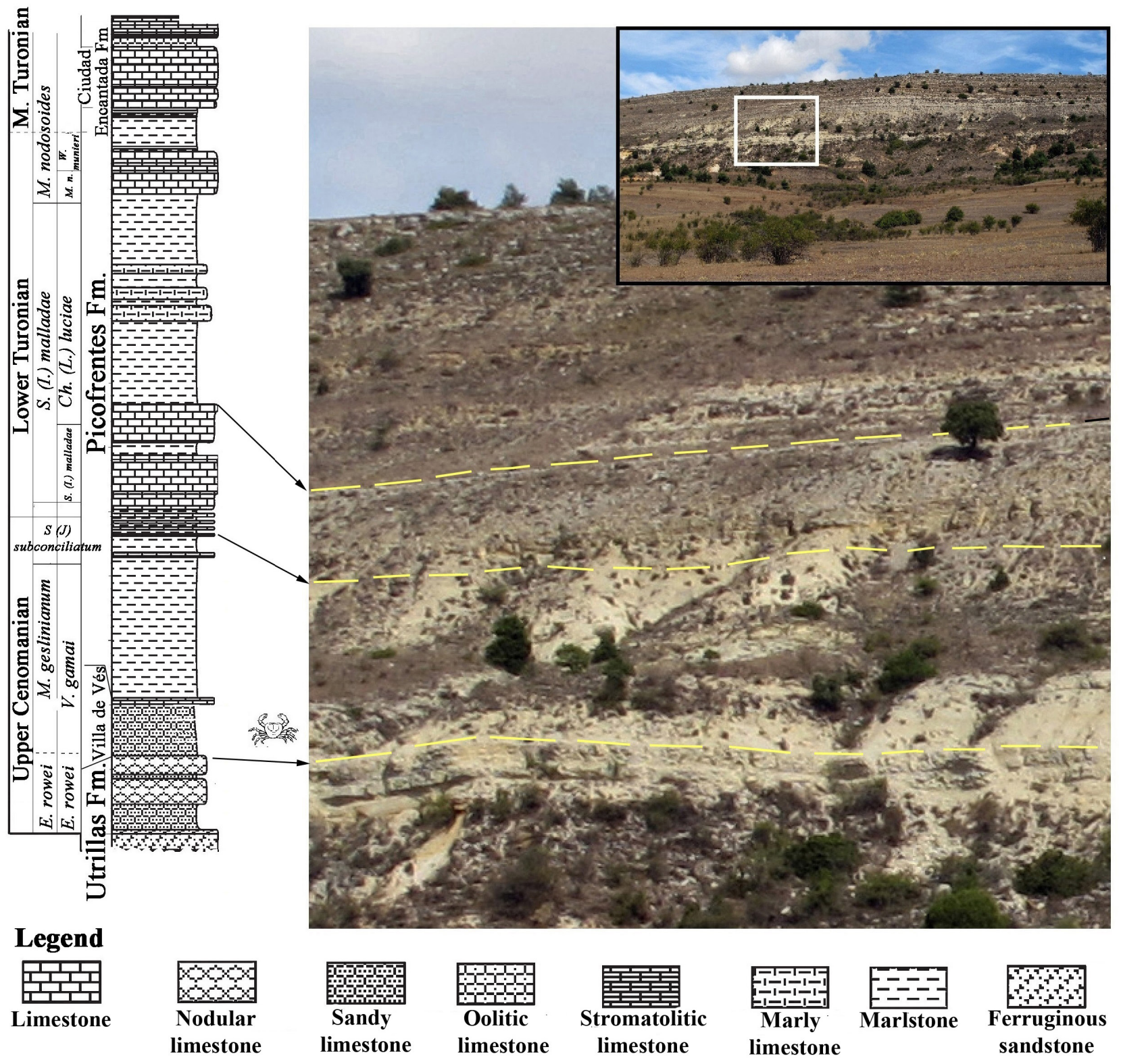

Figure 3. Stratigraphic column and schematic distribution of lithostratigraphic units with position of the crustacean-bearing level. Modified from BarrosoBarcenilla et al. (2009) [www.schweizerbart.de] and Barroso-Barcenilla (pers. comm., 2014). (Drawing by Fernando Ari Ferratges Kwekel).

\section{Material}

Holotype MGB 69151, male, with decorticated carapace and front absent, with nearly complete sterno-abdominal structures, and complete right chela. Reconstruction of carapace is based on pictures of a second specimen from the same outcrop, with complete dorsal carapace and front preserved, in private collection, not available for study (a cast of this specimen is deposited at MGB under registration MGB 69152).

\section{Systematic Paleontology}

Order Decapoda Latreille, 1802

Infraorder Brachyura Latreille, 1802

Section Eubrachyura de Saint Laurent, 1980

Subsection Heterotremata Guinot, 1977

Superfamily Portunoidea Rafinesque, 1815

Family Eogeryonidae n. fam.

Type genus. Eogeryon n. gen

Diagnosis. Carapace sub-hexagonal, medium sized, flattened, slightly wider than long, gently convex 
longitudinally at anterior third. Maximum width at anterior third, at level of third anterolateral tooth. Regions fairly defined. Gastric process poorly defined; mesogastric region not defined; protogastric lobes slightly swollen with transverse ridges; epigastric region medially depressed; epibranchial lobe sigmoidal, inflated, ridged; mesobranchial lobe inflated; metabranchial area depressed; urogastric region depressed; cardiac region slightly swollen. Cervical groove V shaped; branchiocardiac grooves deep. Front bilobed, lobes bifid. Orbits large, two supra-orbital fissures, eyestalks well calcified. Lateral margins strongly stepped. Anterolateral margins with four teeth (including exorbital tooth); first and second teeth strong, subtriangular; third tooth conical; fourth tooth (epibranchial) small blunt node. Posterolateral margins slightly convex. Posterior margin straight, rimmed laterally. Sternum relatively narrow; sternite 3 subrectangular; sternite 4 subtrapezoidal elongate, both slightly depressed medially; sternites 3-4 fused; suture 3/4 well distinct by a deep groove; sternites 5-6 subtrapezoidal, laterally downward directed. Episternites 4-5-6 downward directed. Male abdomen narrow, with 6 somites free and telson covering sterno-abdominal cavity; telson subtriangular reaching $2 / 3$ of sternite 4 , somite 4 the broader; somites 1 and 3 subtrapezoidal, transversally narrow, somite 2 not preserved; somites 4-56 , subrectangular becoming progressively narrower, somite 6 twice as high as 4 and 5. Right cheliped strong, smooth; merus massive, smooth; carpus massive, strong inner spine; propodus strong, smooth; dactyli with strong proximal molariform tooth followed by conical teeth. Ambulatory legs P2- P4 proportionally long, smooth, equal, sub-oval in section; P5 not preserved, appears to be smaller, probably subdorsal.

\section{Genus Eogeryon n. gen.}

Type species. Eogeryon elegius n. gen., n. sp.

Etymology. From the Greek Eo-, primeval, early, and Geryon, from Greek mythology, usual in carcinology.

Diagnosis. As for the family

Discussion. Although the most distinctive character for the Heterotremata (Eubrachyura) is the presence of vulvae in thoracic sternites of females (Guinot, 1977), and the holotype of Eogeryon elegius n. gen., n. sp. is clearly a male, there is no doubt on the heterotreme condition of the new genus. The dorsal carapace morphology of the new genus is typical of the Eubrachyura. The general body plan indicates that Eogeryon elegius n. gen., n. sp., is an advanced brachyuran: carapace flattened without transverse grooves, even though its postero-lateral margins are stepped and the branchiostegite are not completely folded under the carapace (Schram, 1980, 1983; Feldmann et al., 2008); front bilobed and relatively large, shape of orbits, straight posterior margin (Dixon et al., 2003, p. 966; Guinot et al., 2013, p. 203); more or less equal ambulatory pereiopods (Schram, 1980, 1983; Feldmann et al., 2008) and massive specialized right chela (Spiridonov et al., 2014). Beyond its eubrachyuran dorsal appearance, the ventral structures are very informative and confirms its heterotreme condition: the thoracic sternum is relatively wide, having a true sternoabdominal cavity, where a relatively narrow abdomen, folded between abdominal sternites $2-3$, is inserted leaving exposed the rest of the sternum (Guinot et al., 2013). According to Guinot and Tavares (2001) all the Eubrachyura (Heterotremata + Thoracotremata) males have the sternum visible in both sides of the abdomen. On the contrary, in Podotremata the male sternum is usually completely covered by the abdomen.

After establishing the heterotreme condition of the new taxon, all the currently known Heterotremata Cretaceous taxa are compared with Eogeryon n. gen., namely: Archaeopus Rathbun, 1908 (?Retroplumidae Gill, 1894); members of Carcineretidae Beurlen, 1930 (Portunoidea Rafinesque, 1815); Componocancer Feldmann, Schweitzer and Green, 2008 (Componocancridae Feldmann, Schweitzer and Green, 2008); Costacopluma Collins and Morris, 1975 (Retroplumidae Gill, 1894); members of Icriocarcinidae Števčić, 2005 (Portunoidea Rafinesque, 1815); Lithophylax A. Milne-Edwards and Brocchi, 1879 (Lithophylacidae Van Straelen, 1936); members of Longusorbiidae Karasawa, Schweitzer and Feldmann, 2008 (Portunoidea Rafinesque, 1815); Marocarcinus Guinot, De Angeli and Garassino, 2008 (Marocarcinidae Guinot, De Angeli and Garassino, 2008); Megaxantho Vega, Feldmann, García-Barrera, Filkorn, Pimentel and Avendaño, 2001 (?Eriphioidea MacLeay, 1838); Ophthalmoplax Rathbun, 1935 (Portunoidea Rafinesque, 1815); Palaeoxanthopsis Beurlen, 1958 (Palaeoxanthopsidae Schweitzer, 2003); Parapirimela Van Straelen, 1937 (?Portunoidea Rafinesque, 1815); Titanocarcinus A. Milne-Edwards, 1864 (Tumidocarcinidae Schweitzer, 2005); and Styracocarcinus Schweitzer and Feldmann, 2012 (?Portunoidea Rafinesque, 1815). Also other admitted Eubrachyura taxa (Luque, 2015, p. 5 and 10) such as: Telamonocarcinidae Larghi, 2004 (?Dorippoidea MacLeay, 1838) and Tepexicarcinidae Luque, 2015 (uncertain Superfamily), are compared with Eogeryon n. gen. as well.

Cretaceous members of the family Retroplumidae such as Costacopluma from Late Cretaceous of Mexico, western Africa, and India, or those who are considered as such, as Archaeopus (see Guinot et al., 2013, pp. 140-141), from Late Cretaceous of the West Coast of the United States and Canada, clearly differ from Eogeryon n. gen. in having a more squarish or transversely ovate and ridged carapace, with a narrow rostrum usually bifid or spatulated, whereas in Eogeryon n. gen. the carapace is subhexagonal, smooth, and the front is larger. Also, they have much broader orbits than the new genus. Differences in sterno-abdominal pattern are very evident, whereas in Costacopluma and Archaeopus the sternum is large and the thoracic sternites are transversely ridged, in Eogeryon n. gen. the sternum is narrower and the thoracic sternites are flattened. Also, members of Retroplumidae possesses a thin and reduced fifth pereiopod 
whereas in the new taxon it appears to be only slightly reduced (see also de Saint Laurent, 1989; McLay, 2006). Members of Carcineretidae such as Carcineretes Beurlen, 1930 from Maastrichtian of Jamaica, Belize and Mexico and Woodbinax Stenzel, 1952 from the Cenomanian of Texas (US) have affinities with Eogeryon n. gen. such as: a bilobed and downturned front; large orbits with two wellmarked fissures; similar outline of carapace; transverse ridges in protograstric lobes; conspicuous swollen epibranchial ridge and mesobranchial lobes; well-marked branchiocardiac groove bounding urogastric and cardiac regions; and a relatively narrow sternum. But they differ from Eogeryon n. gen. in having: a squarish carapace; an axial inflation in the front; not well-defined antero- and posterolateral margins; and broader orbits than Eogeryon n. gen. In addition, they lack the anterolateral teeth that Eogeryon n. gen. possesses. The sterno-abdominal cavity is much deeper in Carcineretes, reaching the sternite 3. Moreover, Vega et al. (2001) mentioned the sternite 8 was visible; however, Schweitzer et al. (2007b) and Karasawa et al. (2008) indicated the sternite 8 was not visible. In any case, in Eogeryon n. gen. sternite 8 is not visible. In addition, the chelae of Carcineretes are keeled in their outer surface whereas in Eogeryon n. gen. they are smooth and much more massive. The P2-4 are equal in size and P5 paddle-like in Carcineretes, whereas in Eogeryon n. gen. the P5 appears to be slightly reduced. Relationships between those taxa could not be discarded but differences appear to be clear (see Withers, 1922; Beurlen, 1930; Guinot and Bréton, 2006; Schweitzer et al., 2007b). Componocancer, the sole member of Componocancroidea from the Albian of Montana (US), has in dorsal view some affinities with Eogeryon n. gen. Even though the holotype and paratypes of Componocancer are poorly preserved dorsally (Feldmann et al., 2008, f. 2 A, B, C, E), the supraorbital margin has two fissures as in Eogeryon n. gen.; Componocancer shows a similar anterolateral margin, mainly regarding the outer orbital tooth, formed by three broad projections (possibly broken triangular teeth) and small last anterolateral tooth (epibranchial) as in Eogeryon n. gen., and the maximum width is also placed at the level of third anterolateral tooth. The regions are fairly marked in both genera, sharing a short $\mathrm{V}$-shaped cervical groove with gastric pits at the same level, a well-marked branchiocardiac groove bounding urogastric and cardiac regions, slightly inflated branchial regions and the pterygostome is similar in shape (see Feldmann et al., 2008, f. 2). However, differences are evident, for instance dorsally Eogeryon n. gen. is more flattened than Componocancer and the general outline is hexagonal, slightly elongate whereas in Componocancer the general outline is rectangular and wider than long. In ventral view, the male sternum of Eogeryon n. gen. is broader than in Componocancer, and sternites 3-4 are less depressed axially, in addition Componocancer has somites 4 and 5 free laterally, while in Eogeryon n. gen. they are fused; in Componocancer sternites 7-8 are reduced in size indicating that P4 and P5 are carried dorsally, in Eogeryon n. gen. sternites 7-8 are not preserved but the coxae of P2-P4 are equal in size, and the remains of arthrodial cavity of P5, even appearing possibly smaller than the rest of periopods, indicates that P5 was not clearly dorsally carried (see also Guinot et al., 2008; Guinot et al., 2013). Members of Icriocarcinidae such as Icriocarcinus Bishop, 1988 and Branchiocarcinus Vega, Feldmann and Sour-Tovar, 1995, from Campanian-Maastrichtian of West and East Coast of the US and Mexico in the Americas (see Phillips et al., 2014), and Cancrixantho Van Straelen, 1934 from Southern France and Catalonia (NE Iberian Peninsula) in Europe, are clearly distinguishable from Eogeryon n. gen. in having: inverted subtrapezoidal carapace, twice as wide as long; very broad orbits without fissures occupying completely anterior margin; long and narrow pseudorostrum; dorsal carapace regions marked by strong transverse ridges and deep cervical groove; wide thoracic sternum and deep sterno-abdominal cavity and keeled spiny chelae. None of these features can be seen in Eogeryon n. gen., beyond the obvious transverse ridges in protogastric lobes, thus ruling out a close relationship with Eogeryon n. gen. (see Téodori et al., 2013; Nyborg et al., 2014). Lithophylax, the sole member of Lithophylacidae Guinot and Bréton, 2006, tentatively placed within Portunoidea (see Karasawa et al., 2008) differs clearly from Eogeryon n. gen. in having an inverted subtrapezoidal carapace with regions well differentiated by grooves; front large, straight, with narrow rostrum; orbits extremely broad with a unique fissure; wide thoracic sternum and broad sterno-abdominal cavity; chelae weakly homodont; P5 subdorsal and markedly reduced. All of these features preclude, at least, a closer relationship with Eogeryon n. gen. (see Guinot and Bréton, 2006). Members of Longusorbiidae such as Longusorbis Richards, 1975 from the Coniacian to Campanian of the Pacific Coast of Northern and Central America, and Binkhorstia Noetling, 1881 from the Maastrichtian of Europe, differs from Eogeryon n. gen. in having: inverted subtrapezoidal to squarish carapace with well-marked regions; front straight with narrow and downturned spatulated rostrum; large orbits and spiny upper margin of chelae (Longusorbis). However, posterolateral margins are similarly stepped and eyestalks are well calcified in Longusorbiidae as in Eogeryon n. gen. Ventrally, similarities are evident, they share with Eogeryon n. gen.: a similar thoracic sternal structure, more or less elongate, widest at level of sternite 5, sternites 3-4 fused, sternite 4 long, sternites 5-6 subtrapezoidal; suture $2 / 3$ complete; suture 3/4 distinct, well-marked by a groove; sutures $4 / 5$ and 5/6 not parallel, and abdominal somites free, somite 6 being the longest. Even though sternite 3 is shorter in Longusorbiidae and the telson seems to be more acute than in Eogeryon n. gen. and in Binkhorstia, the thoracic sternum is broader than in Eogeryon n. gen. The differences notwithstanding, similarities between Longusorbiidae and the new genus cannot be precluded, mainly regarding sternoabdominal characters (see Richards, 1975; Schweitzer et al., 
2003; Fraaije et al., 2006; Schweitzer and Feldmann, 2011). Marocarcinus, the sole member of Marocarcinidae from the Cenomanian of Morocco, has many affinities with Eogeryon n. gen. but also differences. Careful observations of the figures and descriptions in Guinot et al. (2008), and on new material available (author, personal observation), Marocarcinus possesses antero- and posterolateral margins defined, with anterolateral margin armed with four teeth, the first and second ones being subtriangular, as Eogeryon n. gen. possesses. Marocarcinus also has: a similar carapace outline, flattened with regions faintly defined; similar frontal pattern, straight but faintly bilobed, but not four tipped like as in Eogeryon n. gen.; similar orbits with two fissures and well-calcified eyestalks, as in Eogeryon n. gen. Regarding sterno-abdominal characters, a new available male specimen of Marocarcinus (A. Garassino pers. comm., 2014), presents an elongate and ovoid thoracic sternum with maximum width at the level of sternite 5, similar to the Eogeryon n. gen. sternum. However, the suture $2 / 3$ appears to be incomplete in this new male material, although the diagnosis of Guinot et al. (2008) indicates suture 2/3 complete (for female), as in Eogeryon n. gen.; the suture 3/4 is almost complete, only interrupted medially in the male Marocarcinus, whereas it is distinct, only discernible by a well-marked groove in Eogeryon n. gen.; sternite 4 possesses two marked protrusions in both sides of sternoabdominal cavity in Marocarcinus whereas in Eogeryon n. gen., sternite 4 is smooth; also, abdominal somite 5 is as long as somite 6, whereas in Eogeryon n. gen., somite 5 is half the length of somite 6 (A. Garassino pers. comm., 2014). Chelae seems to be strong and massive with marked heterochely as in Eogeryon n. gen., and probably homodonty (see Guinot et al., 2008, f. 2, 3A), but in Eogeryon n. gen. right chela is even stronger and dactily are clearly heterodontic. According to the above-mentioned similarities between both genera, a possible relationship could exist. Megaxantho Vega, Feldmann, García-Barrera, Filkorn, Pimentel and Avendaño, 2001, tentatively placed in Xanthoidea, could be placed into Menippidae Ortmann, 1893 (Eriphioidea: F. Vega pers. comm., 2015). Megaxantho differs from Eogeryon n. gen. in having: a more flattened and slightly broader carapace; larger front and smaller orbits; rectangular anterolateral teeth whereas in Eogeryon n. gen. they are pointed subtriangular; dactylus of right chela has a strong eccentric basal tooth, whereas in Eogeryon n. sp. it is flattened. Ventrally, differences are not so evident, but Megaxantho has more elongate sternites 3-4, broader somite 6 and telson is more acute subtriangular than in Eogeryon n. gen. (see Vega et al., 2001). Ophthalmoplax (?Macropipinae Stephenson and Campbell, 1960) from the late Campanian of Morocco and Maastrichtian of Atlantic and Gulf coasts of the Americas, differs from Eogeryon n. gen. (as in the case of Carcineretidae) in having: a subquadrate carapace with not well-defined lateral margins; regions well defined, many of them ridged, while in Eogeryon n. sp. regions are poorly defined and ridges are present only in protogastric lobes; posterolateral margins are rimmed, spiny or nodose; fronto-orbital margin is broader in Ophthalmoplax than in Eogeryon n. gen.; supraorbital margin presents stronger spines than in Eogeryon $\mathrm{n}$. gen.; front is bilobed and strongly downturned, but not with four- tipped appearance as in Eogeryon n. gen.; sternite 4 is broader; sterno-abdominal cavity is deeper than in Eogeryon n. sp., and it reaches sternite 3; sternite 8 is visible ventrally in Ophthalmoplax in contrary to Eogeryon n. gen. in which it is not visible. In addition, in Ophthalmoplax chelae are keeled and spiny whereas in Eogeryon n. gen. they are stronger and smooth, and Ophthalmoplax has a lanceolate propodus of P5, not present in Eogeryon n. gen. Possible relationships, if existing, are remote (see Rathbun, 1935; Karasawa et al., 2008; Ossó-Morales et al., 2010; Vega et al., 2013). Parapirimela Van Straelen, 1937 (?Portunoidea), erected to accommodate the portunoid-like Parapirimela Van Straelen, 1937 from Angola, was first assigned to Miocene, but subsequently assigned with reservations to Albian by da Veiga-Ferreira (1957), has a similar anterolateral margin with well-developed subtriangular teeth, and massive right chela, but differs clearly from Eogeryon n. gen. in having an uneven number of frontal spines, well-marked regions and grooves, and having right chela with knobstick molariform tooth in polex instead of dactylus as is usually the case (Van Straelen, 1937; Veiga-Ferreira, 1957). Palaeoxanthopsis Beurlen, 1958, the Cretaceous member of Palaeoxanthopsidae Schweitzer, 2003, from the Maastrichtian of Brazil and Mexico, clearly differs from Eogeryon n. gen. in having: a strongly vaulted longitudinally carapace, wider than long, maximum width about two-thirds posteriorly at level of last anterolateral spine (epibranchial), which is long and posterolaterally directed; and regions well defined by deep grooves, inflated, with spherical swellings. Only the four tipped aspect of its bilobed front is similar to the new genus (see Beurlen, 1958; Schweitzer, 2003, p. 21, fig. 5, 4-5). Cretaceous species of Titanocarcinus A. Milne-Edwards, 1864 (Tumidocarcinidae) such as T. mamillatus Secrétan, 1964 from the Late Cretaceous of Madagascar, differs clearly from Eogeryon n. gen. in having: a subquadrate carapace, moderately vaulted; regions well marked by deep grooves, granular, instead of smooth and fairly marked regions in Eogeryon n. gen., and by absence of triangular teeth in its anterolateral margins as in Eogeryon n. sp. (see Schweitzer et al., 2007a; Charbonnier et al., 2012). Styracocarcinus, genus erected to accommodate Titanocarcinus meridionalis Secrétan, 1961 from the Late Cretaceous of Morocco, questionably placed within Tumidocarcinidae on the basis of its Y-shaped sternum (see Schweitzer and Feldmann, 2012) but that shows clear portunoid affinities, shows similarities with Eogeryon n. gen. Thorough observation of the images presented in Sécretan, 1961, a cast of the holotype in Schweitzer and Feldmann (2012), and of new material available (Figure 6 A-B), from the Late Cretaceous (probably Campanian) of 
the Moyenne Moulouya (Morocco), which presents wellpreserved fronto-orbital features, shows that both genera share: similar flattened subhexagonal carapace, maximum width at level of third anterolateral tooth; regions faintly marked, transverse ridges on protogastric lobes, conspicuous sigmoidal epibranchial ridge, hepatic swellings; deep branchiocardiac grooves; stepped posterolateral margins; front bilobed, four-tipped appearance; orbits relatively large with two supraorbital fissures; anterolateral margin with four teeth, first (exo-orbital) and second ones subtriangular, serrated or slightly nodose outer margin; similar elongate and ovoid thoracic sternum; and a strong and massive right chela of adult specimens (slightly spiny in juvenile specimens of Styracocarcinus). Differences, however, are present. Styracocarcinus possesses: regions of carapace more rounded and slightly inflated; not so clearly marked protogastric ridges; developed epigastric swellings; subtriangular third and fourth anterolateral teeth as the first and second; lobes or teeth in posterolateral margins (spiny in juvenile specimens); slightly narrower thoracic sternum; suture 3/4 laterally visible, suture 4/5 laterally directed whereas in Eogeryon n. gen. it is downward directed; telson more acute, and somite 6 higher than the somite 6 of Eogeryon n. gen. In addition, in Styracocarcinus, the propodus of P4-P5 are flattened, which are not preserved in Eogeryon n. gen. Despite these differences, relationships between both genera are possible (Secrétan, 1961; Schweitzer and Feldmann, 2012, p. 23-25, fig.1, 1-3).

Members of Telamonocarcinidae, Larghi, 2004, such as Telamonocarcinus Larghi, 2004 and Eodorippe Glaessner, 1980, from the Cretaceous of Colombia, Lebanon, Japan and New Zealand, differ from Eogeryon n. gen. by its general appearance, in having: a broadly pyriform carapace, granulate; broader front and narrow rostrum; anterolateral margin without spines; and P4 and P5 reduced (see Larghi, 2004; Guinot et al., 2013; Luque, 2015). Tepexicarcinus Feldmann, Vega, Applegate and Bishop, 1998 (Tepexicarcinidae, Luque, 2015) from the Cretaceous of Mexico and Egypt differs clearly from Eogeryon n. gen. in having: a subrectangular carapace; broader fronto-orbital margin; square rostrum; nearly parallel posterolateral margins, among other evident differences. (See Feldmann et al., 1998; Vega et al., 2005; Larghi, 2004; Guinot et al., 2013; Luque, 2015).

As is indicated above, Eogeryon n. gen. is an advanced crab, but its systematic placement is unclear. As it is seen in the precedent comparisons, it seems to be only related with some of the Late Cretaceous heterotrematous taxa, mainly with the coeval Marocarcinus and/or other younger taxa such as members of Carcineretidae or Longusorbiidae, both Portunoidea, and Styracocarcinus (probably Portunoidea). In many aspects, general dorsal appearance of Eogeryon n. gen. recalls that of some portunoids, regarding its anterolateral margin with acute teeth, and transverse ridges in several regions (see Karasawa et al., 2008). Also, dactylus of its massive right chela present well- differentiated and specialized teeth (see Spiridonov et al., 2014). Based upon the diagnosis of Portunoidea, the Eogeryon n. gen. features fit with several of the mentioned characters: "carapace subhexagonal... generally wider than long but occasionally equant... front typically with median notch... anterolateral margins almost always spinose or dentate, ranging from 3-9 spines or lobes... regions poorly or moderately defined, carapace with arcuate epibranchial ridge..." (Karasawa et al., 2008, p. 94), "fronto-orbital margin broader than posterior margin... chelipeds usually robust, heterolochelic and/or heterodontic..." (Spiridonov et al., 2014, p. 418). Nevertheless, regarding sterno-abdominal characters, even taking account that the holotype is ventrally incomplete, Eogeryon n. gen. does not present the typically portunid appearance as is evident in many of the portunoid families, for instance: usually large and flattened sternum, sternite 8 visible, inverted T-shaped male abdomen, somites 3-5 fused, somite 3 keeled, and neither the paddle-like 5 th pereiopod, which is very usual in this superfamily. However, Eogeryon n. gen. has apparent affinities with some fossil portunoidlike taxa and also with the non-swimming portunoid family Geryonidae Colosi, 1923, which belonging to the Portunoidea, as already suggested by Manning and Holthuis (1981, p. 110) and admitted by Bowman and Abele (1982, p. 24). The portunoid status of Geryonidae is well supported by cladograms based on external morphology of Portunoidea from Karasawa et al. (2008, figs. 3-6) and cladograms based on molecular methods using two independent sources of DNA sequences as nuclear and mitochondrial genes by Schubart and Reuschel (2009, fig. 1) and Spiridonov et al. (2014, figs. 4-7), which place the clade Geryonidae, without exception, as the most basal Portunoidea.

Affinities among Eogeryon n. gen. and Geryonidae are observed, for instance: "carapace hexagonal, wider than long, smooth to granular, regions weakly or moderately defined, often with arcuate ridge on epibranchial area; front with even number of spines and axial notch; orbits only moderately wide, fissured, inner orbital angle defined by a node or spine, lower orbital spine long, visible dorsally; anterolateral margin convex with $3-5$ spines suture $3 / 4$ well marked, sternite 8 not visible" (Karasawa et al., 2008, p. 96), among other affinities regarding chelipeds and thoracic and abdominal features (see also Manning and Holthuis, 1989). Previously, some authors have suggested the possible Cretaceous origins of Geryonidae. For instance, Karasawa et al. (2008, p. 115) indicate: "The positions of Carcineretidae and Ophthalmoplax in the cladogram suggest that Geryonidae, Mathildellidae, Catoptridae, and Carcinidae must have had Cretaceous origins, but as yet there are no fossils to support this hypothesis... Thus, it appears that Portunoidea in general, and especially the more derived groups, are a geologically young group. Indeed, they have geologically older relatives, extending into the Eocene and even the Cretaceous". Also, regarding the evolution of swimming capacities in portunoids, Spiridonov et al. (2014, p. 418) suggested: "Furthermore Geryonidae which have 
many plesiomorphies may be similar to the hypothetical common ancestor and are generally non-swimming or nonregularly swimming forms."

Therefore, Eogeryon n. gen. shares with members of Geryonidae: a smooth sub-hexagonal carapace that is slightly wider than long; regions fairly marked; conspicuous epibranquial ridge; similar cardiac region, swollen; mesobranchial region swollen; gastric pits at level of cervical groove; well-marked branchio-cardiac grooves bounding urogastric region; front bilobed, bifid lobes with four-tipped appearance; similar fronto-orbital ratio; orbits moderately large; supraorbital margin with two fissures or notches; anterolateral margins armed with four spines or teeth (including exo-orbital spine); posterolateral margins convex, stepped; posterior margin straight, re-entrant not well marked; possibly supradorsal position of P5; chelipeds robust, not keeled; merus of cheliped with dorsal subdistal spine; carpus with strong inner spine; propodus massive with dactylus and fixed finger with flattened molariform teeth, followed by serial conical teeth; thoracic sternites 3 and 4 fused, forming an elongate plastron; and suture 3/4 distinct, well-marked by a transversal groove. Nevertheless, differences between Eogeryon n. gen. and members of Geryonidae are also present such as: the epibranchial spine delimiting antero- and posterolateral margins is placed more anteriorly in Geryonidae than in Eogeryon n. gen.; smaller rounded orbits in Geryonidae (rectangular in Zariquieyon Manning and Holthuis, 1989); absence of transverse ridges in protogastric lobes in Geryonidae; outer surface of propodus sometimes ridged in Geryonidae, being smooth in Eogeryon n. gen.; suture 4/5 laterally upward directed whereas they are downward directed in Eogeryon n. gen. as in many primitive Eubrachyura (see Larghi, 2004; Feldmann et al., 2008); male abdomen markedly triangular in Geryonidae, whereas it is subrectangular, narrowing progressively in Eogeryon n. gen.; male somites 3-5 separated by sutures but immovable, whereas they appear completely free in Eogeryon n. gen. (see Karasawa et al., 2008; Spiridonov et al., 2014).

Similarities among Eogeryon n. gen. with other portunoid-like fossil taxa are also observed. In this sense, as it is explained above, the Campanian Styracocarcinus (Figure $6 \mathrm{~A}-\mathrm{B}$ ) presents an array of characters shared with Eogeryon n. gen., as general carapace shape, construction of front, orbits and anterolateral margins, strong heterochelic and heterodontic chelae, and similar ventral pattern with elongate thoracic sternum and abdomen with all somites free, showing clearly their portunoid affinities (sensu Spiridonov et al., 2014). Therefore, Styracocarcinus is herein tentatively transferred to Portunoidea (uncertain Family). As well, some species referred to Coeloma A. Milne-Edwards, 1865 from the Early and Middle Eocene, share with Eogeryon n. gen. a: similar carapace with weakly defined regions; similar orbito-frontal features with four-tipped front and relatively large orbits with fissured or bi-fissured supraorbital margin; chelae with strongly heterochely and clearly heterodonty, carpus with strong inner spine, merus with dorsal sub-distal spine; elongate thoracic sternum with suture $3 / 4$ distinct, discernible by a well-marked groove; male sternite 7 without posterior prolongation; sternite 8 not visible and abdomen with all somites free. The Coeloma species: $C$. dentata (Woodward, 1873), C. glabra (Woodward, 1873) (types species) C. martinezensis Rathbun, 1926 and C. vareoloata Lörenthey, 1898, are considered primitive and grouped in a first group by Jagt et al. (2010, p. 247), following Beurlen in Lörenthey and Beurlen (1929, p. 241- 243), and were transferred to the genus Litoricola Woodward, 1873 by these authors (p. 247), who considered the name Litoricola valid for these four species. In addition, the same authors (p. 249) pointed out that Pedro Artal (pers. comm., May 2010) had informed them that based upon a suite of crabs, referred to as Litoricola by Woodward (1873), in the collections of the Sedgwick Museum, Cambridge, placement of the Ypresian (early Eocene) subspecies Xanthilites macrodactylus pyrenaicus Artal and Via, 1989 in that genus could be confirmed. However, they do not mention the Thanetian (late Paleocene) Xanthilites macrodactylus Van Straelen, 1924 (=Coeloma, see Schweitzer et al., 2010), which is herein provisionally referred to the genus Litoricola as well. Litoricola macrodactylus (Van Straelen, 1924), presents all the characters above described, showing furthermore an extraordinary variability of chelae, being documented specimens with the upper margin of chelae either spiny or smooth, either massive and short or extremely long portunoid-like major chela, (see also Van Straelen, 1924; Schweitzer et al., 2010, Pl. 1, figs. 1A-B, 2A; Goret et al., 2013, figs. 26, Pl. E4, 7, 8, 9; Figure 6 C-E). Affinities of Litoricola with Portunoidea (sensu Spiridonov et al., 2104) appear to be evident, and although there are differences, many of these characters are shared with the most basal non-swimming portunoids Geryonidae (Geryoninae Colosi, 1923 and Benthochasconinae Spiridonov, Neretina and Schepetov, 2014). Thus, until a review of this group is made, as it was suggested by Jagt et al. (2010, p. 246), a provisional placement of Litoricola within Geryonidae, seems to be more appropriate, as it was previously placed (Beurlen, 1930; Balss, 1957; Glaessner, 1969; Karasawa and Schweitzer, 2006), than their current placement as Coeloma, within Mathildellidae Karasawa and Kato, 2003 (Goneplacoidea MacLeay, 1838). It is noteworthy that in the above-mentioned genera and species, a progressive displacement of the epibranchial spine or corner marking the separation between the antero- and posterolateral margins is observed, from approximately half of carapace in Eogeryon n. gen., toward the anterior third of carapace in Litoricola martinezensis (see Rathbun, 1926, Pl. 2fig.13), L. dentata (Figure 6 F-I) and members of Geryonidae, with intermediate positions in Styracocarcinus meridionalis and L. macrodactylus (Figure $6 \mathrm{~A}-\mathrm{E}$ ). Other progressive variations are observed: the angle of sternal suture $4 / 5$, whereas it is downward directed in Eogeryon n. gen., it is laterally directed in S. meridionalis, and progressively 
upward directed in L. macrodactylus, L. macrodactylus pyrenaicus, L. martinezensis and in Geryonidae; and in the same order, a progressive widening of the male abdomen is observed, becoming subtriangular in Geryonidae instead of subrectangular in Eogeryon n. gen. (see Rathbun, 1926; Artal and Via, 1989; Karasawa et al., 2008; Jagt et al., 2010; Schweitzer and Feldmann, 2012; Goret et al., 2013; Spiridonov et al., 2014; Figure 6).

However, the presence of well-marked transverse ridges in the protogastric lobes in Eogeryon n. gen. is not seen in any of the above-mentioned fossil taxa, nor in Geryonidae, thus blurring a potential direct phylogenetic relationship among Eogeryon n. gen. and the extant Geryonidae through some intermediate fossil taxa. Therefore, if the placement of Eogeryon n. gen. within Portunoidea seems to be appropriate, its familial placement is still obscure, despite the array of affinities with Geryonidae and related abovementioned taxa. Therefore, none of Portunoidea known families can accommodate the new taxon, although some early Eocene portunoid fossil taxa, for instance Pleolobites Rémy, 1960 and Portunites Bell, 1858, currently included in the Macropipinae within Polybiidae (sensu Schubart and Reuschel, 2009), share with Eogeryon n. gen. a similar fronto-orbital pattern as front bilobed and four-tipped like and relatively broad orbits with supraorbital margin bi-fissured, as possible plesiomorphies. In addition, they share a relatively broad thoracic sternum, suture 3/4 well defined by a groove, sternite 8 not visible, and male somites completely free. However, they differs from Eogeryon n. gen. in having a broader carapace with well-marked regions, absence of ridges, and regarding Pleolobites in having keeled and spiny chelae (see Rémy, 1960, p. 59, Figure. 4, T1, 10-11; Bell, 1858, p. 20-22, T. 3, Figure 1-5).

Although it may be very suggestive establishing a direct phylogenetic relationship with Eogeryon n. gen. and the extant Geryonidae through intermediate forms such as the aforementioned, taking account the basal portunoid condition of Geryonidae, it seems more prudent to erect a different family to accommodate Eogeryon n. gen. within Portunoidea until new findings may enlighten our current knowledge. Thus, Eogeryon n. gen. is placed tentatively in its own family Eogeryonidae n. fam.

\section{Eogeryon elegius n. sp.}

Figures 4, 5

Diagnosis. As for the family.

Etymology. From the Latin Elegius, the chosen, dedicated to my son Eloi.

Measurements (in mm.). Holotype MGB 69151, carapace length $=30$, width $=33$, orbito-frontal width $=24$, frontal width $=7$. Cast of second specimen MGB 69152, carapace length $=37$, width $=45$, orbito-frontal width $=32$, frontal width $=12$.

Description. Carapace sub-hexagonal, medium sized, flattened, slightly wider than long, gently convex longitudinally at anterior third, epicuticle smooth. Maximum width at anterior third, at level of third anterolateral tooth. Regions fairly defined. Hepatic region with swollen semicircular lobe, half-moon ridged. Gastric process poorly defined. Epigastric region medially depressed; protogastric lobes slightly swollen with well-marked transverse ridges; mesogastric region not defined; metagastric lobes slightly swollen separated from mesogastric region by deep V-shaped cervical groove; urogastric region fairly marked, depressed; gastric pits present. Cardiac region slightly swollen. Intestinal region depressed. Space between both, urogastric and cardiac regions, bounded by deep cardio-branchial grooves. Epibranchial lobe sigmoidal, inflated, partially ridged; mesobranchial lobe inflated; metabranchial area depressed. Front bilobed, bimarginate, slightly downturned, lobes bifid, four-tipped appearance. Orbits moderately large; supra-orbital margin slightly rimmed, two supra-orbital fissures; eyestalks relatively long, well calcified. Lateral margins strongly stepped, mainly posterolateral margin. Anterolateral margins with four teeth; first anterolateral tooth (exo-orbital), subtriangular, large, inward directed; second anterolateral tooth subtriangular, forward directed, outer margin ornate with very small nodes; third tooth conical, upward directed; fourth anterolateral tooth (epibranchial) small, blunt node. Posterolateral margins convex, stepped. Posterior margin straight, rimmed laterally. Sternum relatively narrow, longitudinally medially concave at level of sternites 3-4; sternites 1-2 not present; sternite 3 subrectangular; sternite 4 subtrapezoidal elongate; sternites 3, 4 fused; suture 3/4 well discernible by a deep transverse groove; sternites 5-6 subtrapezoidal, downward directed laterally, sternal sutures $4 / 5$ and 5/6 not parallel. Episternites 4-5-6 downward directed. Male abdomen narrow, with 6 somites free, and telson covering sterno-abdominal cavity; telson subtriangular reaching $2 / 3$ of sternite 4 , somite 4 the broader; somites 1 and 3 subtrapezoidal, transversally narrow; somite 2 not preserved; somites 4-56 , subrectangular becoming progressively narrower, somite

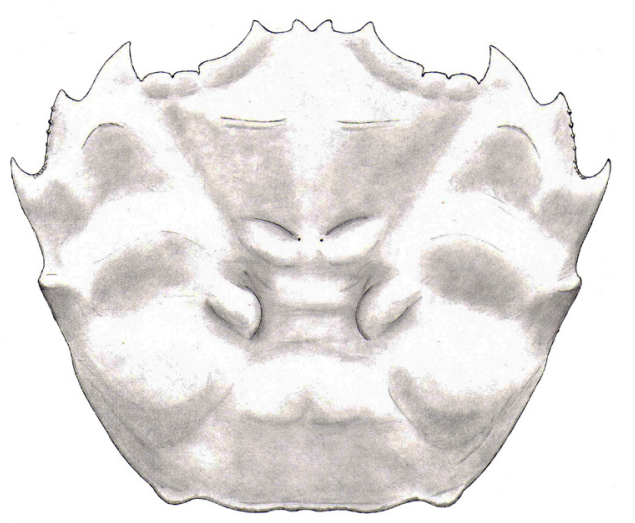

Figure 4. Schematic reconstruction of dorsal carapace of Eogeryon elegius n. gen., n. sp., based on holotype and pictures of a second specimen. (Drawing by Fernando Ari Ferratges Kwekel). 
6 twice as high as 4 and 5. Right cheliped strong, smooth, suggesting marked heterochely; merus with subdistal dorsal spine, carpus massive, with inner strong spine; propodus strong, smooth; dactylus length equal as propodus; both, dactylus and fixed finger with proximal strong, flattened, molariform tooth, followed by five serial conical teeth. Ambulatory legs P2-4 proportionally long, smooth, equal, sub-oval in section; coxae of P2-4 subquadrate, equal; P5 not preserved, appears to be slightly smaller, probably subdorsal
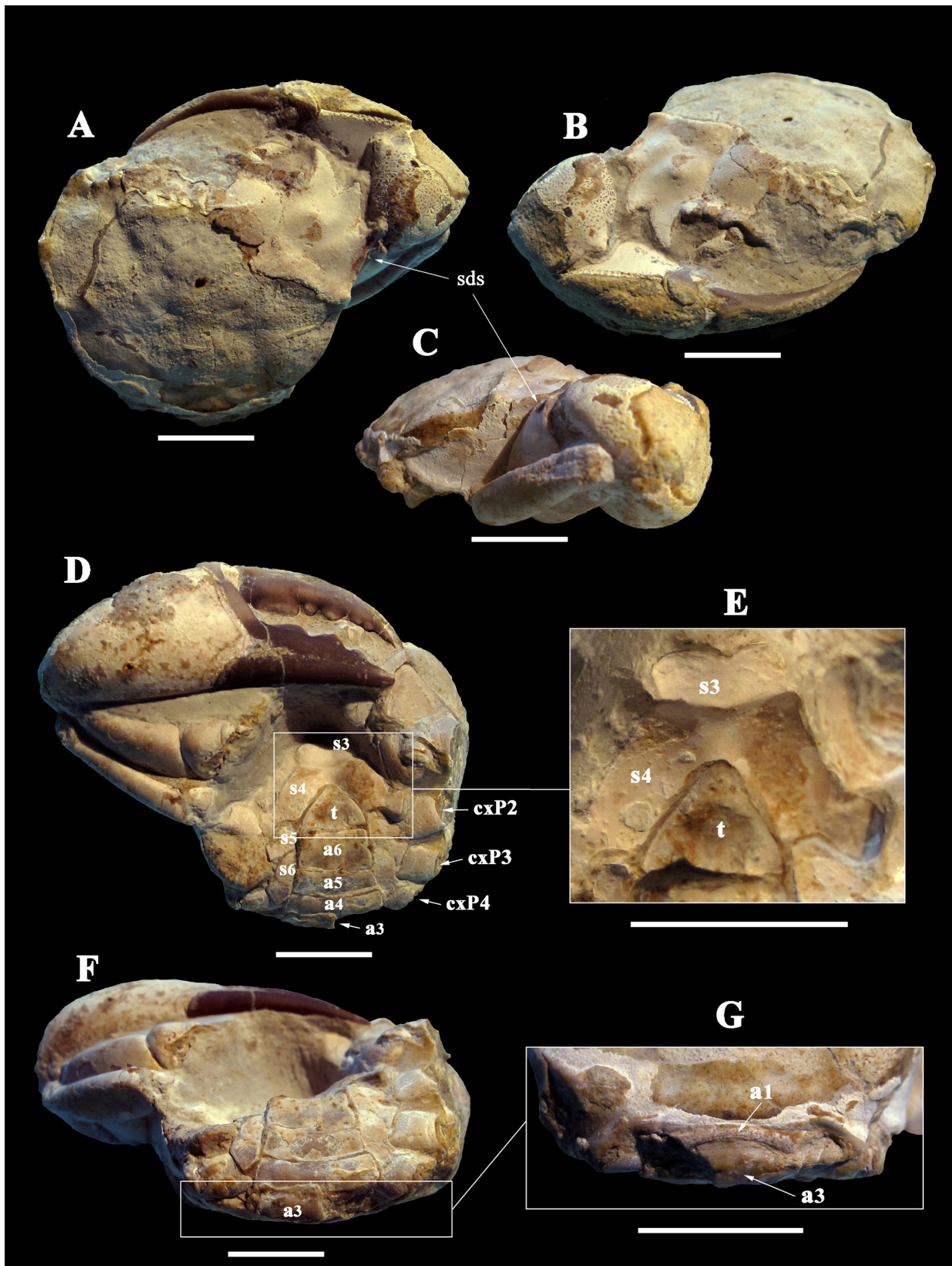

Figure 5. Eogeryon elegius n. gen, n. sp. Holotype MGB 69151, late Cenomanian, Condemios de Arriba (Guadalajara, Spain). A: dorsal view; B: frontal view; C: lateral view; D: ventral view; E: close-up of sternum; F: postero-ventral view; G: close-up of posterior-dorsal view. Abbreviations: $\mathrm{a}=\mathrm{abdominal}$ somite; $\mathrm{cxP}=$ coxa of pereiopod; $\mathrm{s}=$ thoracic sternite; $\mathrm{sds}=$ dorsal subdistal spine; $\mathrm{t}=$ telson. 


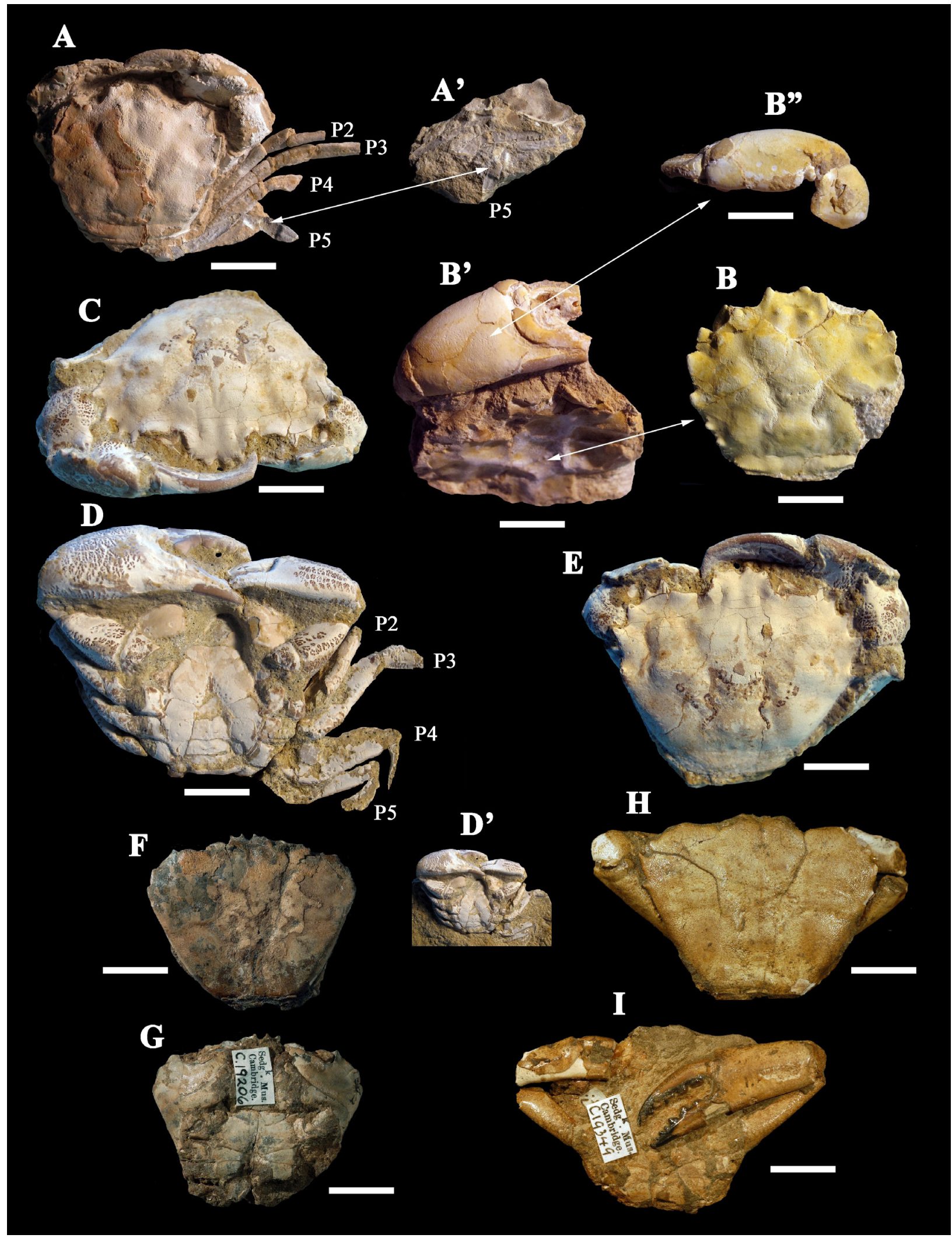

Figure 6. A, B: Styracocarcinus meridionalis (Sécretan, 1961) from probably Campanian, Moyenne Moulouya, Morocco; A, MGB 69153: dorsal view; A': remain of propodus of P5, digitally transferred from matrix to the specimen; B, MGB 69154: dorsal view; B': counterpart with right chela attached to the matrix; B": dorsal view of right chela. C, D, E: Litoricola macrodactylus (Van Straelen, 1924) MGB 69155 from the lower Thanetian (Paleocene), Boussens, Haute-Garonne, France; C: frontal view; D: ventral view; D': same specimen attached to the matrix; E: dorsal view. F, G, H, I: Litoricola Woodward, 1873 from the Ypresian of Portsmouth, Hampshire, United Kingdom; F, G: L. cfr. dentata Woodward, 1873 SGC C19206; F: dorsal view; G: ventral view; H, I: L. dentata Woodward, 1873 SGC C19349; H: dorsal view; I: ventral view. 


\section{Final remarks}

The surprising discovery of Eogeryon elegius n. gen., n. sp. in late Cenomanian rocks allows a new insight on the eubrachyuran decapod evolution. Compared with other coeval or older eubrachyuran taxa, Eogeryon elegius n. gen., n. sp. appears to be an advanced Eubrachyura, much more so than might be expected by its old age. If compared with Albian taxa such as Dorippoidea, admitted as the oldest known eubrachyurans (see Luque, 2015), whether with the Albian Componocancer roberti Feldmann, Schweitzer and Green, 2008 or its coeval Marocarcinus pasinii Guinot, De Angeli and Garassino, 2008, Eogeryon elegius n. gen., n. sp. presents a higher degree of carcinisation, suggesting that it evolved from ancestral forms during the earliest Cretaceous. Moreover, the African portunoidlike Parapirimela angolensis Van Straelen, 1937, if its Albian age is confirmed, would represent the oldest known advanced eubrachyuran. The Portunoidea, despite their old origins, confirmed herein, are shown as more advanced eubrachyuran, in contrary to the primitive Dorippoidea, which are considered one of the most basal eubrachyuran groups. Portunoidea appears to be the most diverse and well-represented Eubrachyura group in the Cretaceous as demonstrated by the occurrence of Eogeryon elegius n. gen., n. sp., the portunoid-like Parapirimela, the possible portunoid Lithophylax during the Middle Cretaceous, and by the numerous taxa and families during the Late Cretaceous, such as members of Carcineretidae, Icriocarcinidae and Longusorbiidae or Ophthalmoplax and Styracocarcinus. It is noteworthy that these Late Cretaceous portunoid taxa present a random combination of typical characters seen in the most derived portunoids such as: a carapace broader than long often with epibranchial ridge; sternite 8 visible; inverted T-shape abdomen; transverse keel in somite 3; keeled and/or spiny chelae; modified paddle-like P5. However, none of these characteristics are present as a whole. It is not until the middle-late Eocene that, according to the fossil record, representatives of Portunidae sensu stricto appear, adding to the array of characters previously cited, the fusion of somites 3,4 and 5, which is typical for this family and many other portunoid families. Therefore, apparently, the typical portunid ventral features cannot be expected in most of Cretaceous and Paleocene portunoid genera. The fossil record shows how Portunoidea were well recovered after the $\mathrm{K} / \mathrm{P}$ event and the Early Eocene, a time of diversification for this group. For example, the Ypresian genus Archaeoportunus Artal, Ossó and Domínguez, 2013 (Archaeoportunidae) shows clearly how under a completely portunid-like carapace and with paddle-like P5 (author pers. obs.), its thoracic sternum and abdomen do not correspond to the typical portunid-like ventral features (see Artal et al., 2013). Therefore, Eogeryon elegius n. gen., n. sp. appears as one of the ancestors of portunoid forms that, through intermediate forms, originated one of the most diverse and species-rich groups of Eubrachyura. Further discoveries in other Late Cretaceous strata, such as Coniacian and Santonian, which have the poorest eubrachyuran fossil record, should enlighten our current knowledge.

\section{Acronyms}

MGB: Museu de Geologia de Barcelona; SGC: Sedgwick Museum of Earth Sciences, Cambridge.

\section{Acknowledgements}

My gratitude to an anonymous collector who found and kindly donated the holotype, and to another anonymous collector who provided pictures and a cast of the second specimen. I'm indebted to Fernando Barroso Barcenilla (UCM, Madrid, Spain) for his important help on the regional geology and providing important literature. M. Segura (UAH, Alcalá de Henares, Spain) for comments on stratigraphy. José Luis Domínguez (Zaragoza, Spain) for useful comments and field assistance. Barry Van Bakel (Oertijdmuseum De Groene Poort, Boxtel, Netherlands) for useful comments and kindly providing pictures of comparative samples and important literature. Fernando Ari Ferratges Kwekel (UAB, Barcelona, Catalonia) for drawing the sketch. I'm grateful as well to Alessandro Garassino (Natural History Museum, Milano, Italy) and Torrey Nyborg (Loma Linda University, Loma Linda, California, USA) for their accurate and constructive reviews that improved the present paper.

\section{References}

Aguilar, M.J., Ramírez del Pozo, J., Riba, O., 1971, Algunas precisiones sobre la sedimentación y paleoecología del Cretácico Inferior en la Zona de Utrillas-Villarroya de los Pinares (Teruel): Estudios Geológicos, 27, 497-512.

Artal, P., Ossó, À., Domínguez, J.L., 2013, Archaeoportunus isabenensis, a new genus and species of portunoid crab (Crustacea, Decapoda) from the lower Eocene of Huesca (Spain): Boletín de la Sociedad Geológica Mexicana, 65(2), 307-317.

Artal, P., Vía, L., 1989, Xanthilites macrodactylus pyrenaicus (Crustacea, Decapoda) nueva subespecie del Ilerdiense medio del Pirineo de Huesca: Batalleria, 2, 57-61.

Balss, H., 1957, Decapoda, 1505-1672, in, Dr. H. G. Bronns, Klassen und Ordnungen des Tierreichs Funfter: Band 5, Abteilung 1, Buch 7. Lieferung.

Barroso-Barcenilla, F., Callapez, P.M., Ferreira Soares, A., Segura, M., 2011, Cephalopod assemblages and depositional sequences from the upper Cenomanian and lower Turonian of the Iberian Peninsula (Spain and Portugal): Journal of Iberian Geology, 37(1), 9-28.

Barroso-Barcenilla, F., Goy, A., Segura, M., 2009, Ammonite zonation of the Upper Cenomanian and Lower Turonian in the Iberian Trough, Spain: Newletters on Stratigraphy, 43, 139-164. 
Bell, T., 1858, A monograph of the fossil malacostracous Crustacea of Great Britain, Pt. I, Crustacea of the London Clay: Monograph of the Palaeontographical Society, London, 10 [1856]: i-viii, 1-44.

Beurlen, K., 1930, Vergleichende Stammesgeschichte Grundlagen, Methoden, Probleme unter besonderer Berücksichtigung der höheren Krebse: Fortschritte der Geologie und Palaeontologie, 8(26), 317-586.

Beurlen, K., 1958, Dois crustáceos do Cretáceo Superior do Nordeste do Brasil: Boletim do Museu Nacional, Geologia, 26, 1-21.

Bishop, G.A., 1988, Two crabs, Xandaros sternbergi (Rathbun, 1926) n. gen., and Icriocarcinus xestos n. gen., n. sp., from the Late Cretaceous of San Diego County, California, USA, and Baja California Norte, Mexico: Transactions of the San Diego Society of Natural History, 21, 245-257.

Bowman, T. E., Abele, L.G., 1982, Classification of the Recent Crustacea, in Abele, L.G. (ed.), Systematics, the fossil record, and biogeography: The Biology of Crustacea, Vol. 1, Academic Press, New York, 1-27.

Caus, E., Bernaus, J.M., Calonge, E., Martin-Chivelet, J., 2009, MidCenomanian separation of Atlantic and Tethyan domains in Iberia by a land-bridge: the origin of larger foraminifera provinces? Palaeogeography, Palaeodimatology, Palaeoecology, 283, 172-181.

Charbonnier, S., Garassino, A., Pasini, G., 2012, Revision of Mesozoic decapod crustaceans from Madagascar: Geodiversitas 34(2), 313357.

Choffat, P.L., 1898, Recueil d'études paléontologiques sur la Faune Crétacique du Portugal, II : Section des Travaux Géologiques du Portugal, Lisbonne: 45 p.

Collins, J.S.H., Morris, S.F., 1975, A new crab, Costacopluma concava, from the upper Cretaceous of Nigeria: Palaeontology, 18(4), 823829.

Colosi, G., 1923, Una specie fossile de Gerionide (Decapodi brachiuri): Bolletino della Società dei Naturisti in Napoli, series 2, 15, 248-255.

Dixon, C.J., Ahyong, S.T., Schram, F.R., 2003, A new hypothesis of decapod phylogeny: Crustaceana, 76(8), 935-975.

Feldmann, R.M., Schweitzer, C.E., Green, R., 2008, Unusual Albian (Early Cretaceous) Brachyura (Homoloidea: Componocancroidea new superfamily) from Montana and Wyoming, U.S.A: Journal of Crustacean Biology, 28(3), 502-509.

Feldmann, R.M., Vega, F.J., Applegate, S.P., Bishop, G.A., 1998, Early Cretaceous arthropods from the Tlayúa formation at Tepexi de Rodríguez, Puebla, México: Journal of Paleontology, 72, 79-90.

Floquet, M., Alonso, A., Meléndez, A., 1982, El Cretácico Superior de Cameros-Castilla, in García, A. (Ed.), El Cretácico de España. Universidad Complutense de Madrid, Madrid, 387-456.

Fraaije, R.H.B., Vega, F.J., van Bakel, B.W.M., Garibay-Romero, L.M., 2006, Late Cretaceous dwarf decapods from Guerrero, southern Mexico and their migration patterns: Contributions to Zoology, $75,121-132$.

Gill, T., 1894, A new Bassalian type of crabs: American Naturalist, 28, 1043-1045.

Glaessner, M.F., 1969, Decapoda, in Moore, R.C. (ed.), Treatise on Invertebrate Paleontology, Pt. R4(2). Geological Society of America, Boulder, Colorado, and University of Kansas Press, Lawrence, Kansas, R400-R533, R626-R628 p.

Glaessner, M.F., 1980, New Cretaceous and Tertiary crabs (Crustacea: Brachyura) from Australia and New Zealand: Transactions of the Royal Society of South Australia, 104, 171-192.

Goret, B., Téodori, D., Lebrun, P., 2013, Le Crétacé-Paléogène des Petites Pyrénées, des fossiles en Haute-Garonne et Ariège: Fossiles, 16, 44-58.

Guinot, D., 1977, Proposition pour une nouvelle classification des Crustacés Décapodes Brachyoures: Comptes Rendus hebdomadaires des séances de l'Academie des Sciences (Paris), D, 285, 1049-1052.

Guinot, D., Breton, G., 2006, Lithophylax trigeri A. Milne-Edwards and Brocchi, 1879 from the French Cretaceous (Cenomanian) and placement of the family Lithophylacidae Van Straelen, 1936 (Crustacea, Decapoda, Brachyura): Geodiversitas: 28(4), 591-633.
Guinot, D., De Angeli, A., Garassino, A., 2008, Marocarcinidae, a new eubrachyuran family, and Marocarcinus pasinii n. gen., n. sp. from the Upper Cretaceous (Cenomanian-Turonian) of Gara Sbaa, southeastern Morocco (Crustacea, Decapoda, Brachyura): Atti della Società Italiana di Scienze Naturali e del Museo Civico di Storia Naturale in Milano, 149(1), 25-36.

Guinot, D., Tavares, M., 2001, Une nouvelle famille de crabes du Crétacé, et la notion de Podotremata Guinot, 1977 (Crustacea, Decapoda, Brachyura): Zoosystema, 23(3), 507-546.

Guinot, D., Tavares, M., Castro, P., 2013, Significance of the sexual openings and supplementary structures on the phylogeny of brachyuran crabs (Crustacea, Decapoda, Brachyura), with new nomina for higher-ranked podotreme taxa: Zootaxa, 3665(1), 414.

Jagt, J.W.M., Van Bakel, B.W.M., Fraaije, R.H.B., 2010, Coeloma rupeliense (Crustacea, Decapoda, Brachyura) from the Bilzen Formation (Rupel Group, Lower Oligocene) in northeast Belgium: Bulletin De L'institut Royal des Sciences Naturelles de Belgique, Sciences de la Terre, 80, 245-252.

Karasawa, H., Kato, H., 2003, The family Goneplacidae MacLeay, 1838 (Crustacea: Decapoda: Brachyura): systematics, phylogeny, and fossil records: Paleontological Research, 7, 129-151.

Karasawa, H., Schweitzer, C.E., 2006, A new classification of the Xanthoidea sensu lato (Crustacea: Decapoda: Brachyura) based on phylogenetic analysis and traditional systematics and evaluation of all fossil Xanthoidea sensu lato: Contributions to Zoology, 75 $(1 / 2)$ 23-73.

Karasawa, H., Schweitzer, C.E., Feldmann, R.M., 2008, Revision of the Portunoidea Rafinesque, 1815 (Decapoda: Brachyura) with emphasis on the fossil genera and families: Journal of Crustacean Biology, 28(1), 82-127.

Larghi, C., 2004, Brachyuran decapod Crustacea from the Upper Cretaceous of Lebanon: Journal of Paleontology, 78, 528-541.

Latreille, P.A., 1802, Histoire naturelle, général et particulière, des Crustacés et des Insectes, Volume 3. Familles naturelles des genres: Paris, Dufart, $467 \mathrm{p}$.

Lörenthey, E., 1898, Beiträge zur Decapodenfauna der ungarischen Tertiärs: Természetrajzi Füzetek, 21, 1-133.

Lőrenthey, E., Beurlen, K., 1929, Die fossilen Dekapoden der Länder derUngarischen Krone: Geologica Hungarica, Series Palaeontologica, 3, $421 \mathrm{p}$.

Luque, J., 2015, The oldest Higher True Crabs (Crustacea: Decapoda: Eubrachyura): insights from the Early Cretaceous of the Americas: Palaeontology, 58(2), 251-263.

McLay, C.L., 2006, Retroplumidae (Crustacea, Decapoda) from the IndoMalayan archipelago (Indonesia, Philippine) and the Melanesian arc islands (Solomon Islands, Fiji and New Caledonia), and paleogeographical comments, in Richer de Forges, B., Justine, J.L. (eds), Tropical Deep-Sea Benthos, 24: Mémoires du Muséum national d'Histoire naturelle, (193), 375-391.

MacLeay, W.S.,1838, On the brachyurous decapod Crustacea brought from the Cape by Dr. Smith, in Smith, A. (ed.), Illustrations of the Annulosa of South Africa; being a portion of the objects of natural history chiefly collected during an expedition into the interior of South Africa, under the direction of Dr. Andrew Smith, in the years 1834, 1835 and 1836; fitted out by "The Cape of Good Hope Association for Exploring Central Africa": Smith, Elder, and Co., London, 53-71.

Manning, R.B., Holthuis, L.B., 1981, West African brachyuran crabs (Crustacea: Decapoda): Smithsonian Contributions to Zoology, 306,1-379.

Manning, R.B., Holthuis, L.B., 1989, Two new genera and nine new species of geryonid crabs (Crustacea, Decapoda, Geryonidae): Proceedings of the Biological Society of Washington, 102(1), 50-77.

Meléndez, F., 1971, Estudio geológico de la Serranía de Cuenca en relación a sus posibilidades petrolíferas, 153-154: Publicaciones de la Facultad de Ciencias de la Universidad Complutense de Madrid, A, 245 p. 
Milne-Edwards, A., 1864, Monographie des Crustacés de la famille Cancériens: Annales des Sciences Naturelles, (Zoologie), (5), 1, 31-88.

Milne-Edwards, A., 1865, Monographie des crustacés de la famille Cancériens: Annales des Sciences naturelles (Zoologie), (5), 3, 297-351.

Milne-Edwards A., Brocchi P., 1879, Note sur quelques crustacés fossiles appartenant au groupe des macrophthalmiens : Bulletin de la Société philomatique, 7, 3, 113-117

Noetling, F., 1881, Ueber einige Brachyuren aus dem Senon von Maestricht und dem Tertiär Norddeutschlands: Zeitschrift der Deutschen Geologischen Gesellschaft, 33, 357-371.

Nyborg, T., Ossó, À., Vega, F.J., 2014, A new species of icriocarcinid crab (Crustacea, Portunoidea) fom the uppermost Cretaceous of California, USA: palaeobiogeographic implications, in Fraaije, R.H.B., Hyžný, M., Jagt, J.W.M., Krobicki, M.,Van Bakel, B.W.M. (eds.), Proceedings of the 5th Symposium on Mesozoic and Cenozoic Decapod Crustaceans, Krakow, Poland, 2013: A tribute to Pál Mihály Müller: Scripta Geologica, 147, 83-93.

Ortmann, A., 1893, Abtheilung: Brachyura (Brachyura genuina Boas), II. Unterabtheilung: Cancroidea, 2. Section: Cancrinea, 1. Gruppe: Cyclometopa. Die Decapoden-Krebse des Strassburger Museums, mit besonderer Berücksichtigung der von Herrn Dr. Döderlein bei Japan und bei den Liu-Kiu-Inseln gesammelten und zur Zeit im Strassburger Museum aufbewahrten Formen, VII Theil: Zoologische Jahrbücher, (Systematik, Geographie und Biologie der Thiere, 7, 411-495.

Ossó-Morales, À., Artal, P., Vega, F.J., 2010, New crabs (Crustacea, Decapoda) from the Upper Cretaceous (Campanian) of the Moyenne Moulouya, northeast Morocco: Revista Mexicana de Ciencias Geológicas, 27, 213-224.

Peyrot, D., Barroso-Barcenilla, F., Feist-Burkhardt, S., 2012, Palaeoenvironmental controls on late Cenomanian-early Turonian dinoflagellate cyst assemblages from Condemios (Central Spain): Review of Palaeobotany and Palynology, 180, 25-40.

Philip, J., Floquet, M., 2000, Late Cenomanian, in Dercourt, J., Gaetani, M., Vrielynck, B., Barrier, E., Biju-Duval, B., Brunet, M.F., Cadet, J.P., Crasquin, S., Sandulescu, M. (eds.), Atlas Peri-Tethys. CVGM/ CGMV, Map 14, Paris.

Phillips, G.E., Nyborg, T., Vega, F.J., 2014, Icriocarcinidae, a family of portunoid crabs from the Upper Cretaceous of North America: Paläontologische Zeitschrift, 88, 139-158.

Rafinesque, C.S., 1815, Analyse de la Nature ou Tableau de l'Univers et des Corps Organisés: Jean Barravecchia, Palerme, 230 p.

Rathbun, M.J., 1908, Descriptions of fossil crabs from California: Proceedings of the Biological Society of Washington, 35(1647), 341-349.

Rathbun, M.J., 1926, The fossil stalk-eyed Crustacea of the Pacific slope of North America: Bulletin of the United States National Museum, 138 , viii $+155 \mathrm{p}$

Rathbun, M.J., 1935, Fossil Crustacea of the Atlantic and Gulf Coastal Plain: Geological Society of America, Special Papers, 2, 1-160.

Rémy, J.M., 1960, Études paléontologiques et géologiques sur les falaises de Fresco (Côte-d'Ivoire): II. Crustacés. Annales de la Faculté des Sciences de l'Université de Dakar, 5, 55-64.

Richards, B.C., 1975, Longusorbis coniculosus: a new genus and species of Upper Cretaceous crab; with comments on Spray Formation at Shelter Point, Vancouver Island, British Columbia: Canadian Journal of Earth Sciences, 12, 1850-1863.

Saint Laurent, M. de, 1980, Sur la classification et la phylogénie des Crustacés Décapodes Brachyoures. I. Podotremata Guinot, 1977, et Eubrachyura sect. nov: Comptes Rendus Hebdomadaires des Séances de l'Académie des Sciences, Paris, (D) 290: 1265-1268.

Saint Laurent, M. de, 1989, La nouvelle superfamille des Retroplumoidea Gill, 1894 (Decapoda, Brachyura): systématique, affinités et évolution, in Forest, J. (Ed.), Résultats des Campagnes MUSORSTOM, vol. 5: Mémoires du Muséum national d'Histoire naturelle, A, Zoologie, 144, 103-179.
Schram, F.R., 1980, On the classification of Eumalacostraca: Journal of Crustacean Biology 1: 1-10.

Schram, F.R., 1983, Method and madness in phylogeny, in Schram, F.R. (ed.), Crustacean Phylogeny, A. A. Balkema, Rotterdam, 331-350.

Schubart, C.D., Reuschel, S., 2009, A proposal for a new classification of Portunoidea and Cancroidea (Brachyura: Heterotremata) based on two independent molecular phylogenies, in Martin, J.W., Crandall, K.A., Felder, D.L. (eds.), Decapod Crustacean Phylogenetics (Crustacean Issues Series, 18): Boca Raton, Florida, CRC Press, 533-549.

Schweitzer, C.E., 2003, Utility of Proxy Characters for Classification of Fossils: An Example from the Fossil Xanthoidea (Crustacea: Decapoda: Brachyura): Journal of Paleontology, 77(6), 1107-1128.

Schweitzer, C.E., 2005, The genus Xanthilites Bell, 1858 and a new xanthoid family (Crustacea: Decapoda: Brachyura: Xanthoidea): new hypotheses on the origin of the Xanthoidea MacLeay, 1838: Journal of Paleontology, 79, 277-295.

Schweitzer, C.E., Artal, P., Van Bakel, B., Jagt J.W.M., Karasawa, H., 2007a, Revision of the Genus Titanocarcinus (Decapoda: Brachyura: Xanthoidea) with two new genera and one new species: Journal of Crustacean Biology, 27, 278-295.

Schweitzer, C.E., Feldmann, R.M., 2011, Revision of some fossil podotrematous Brachyura (Homolodromiidae; Longodromitidae; Torynommidae): Neues Jahrbuch für Geologie und Paläontologie Abhandlungen, 260(2), 237-256.

Schweitzer, C.E., Feldmann, R.M., 2012, Revision of Decapoda deposited in The Muséum national d'Histoire naturelle, Paris. Bulletin of the Mizunami Fossil Museum, 38, 15-27.

Schweitzer, C.E., Feldmann, R.M., Fam, J., Hessin, W.A., Hetricks, S.W., Nyborg, T.G., Ross, R.M.L., 2003, Cretaceous and Eocene Decapod Crustaceans from Southern Vancouver Island, British Columbia, Canada: National Research Council Press, Ottawa, 66 p.

Schweitzer, C.E., Feldmann, R.M., Garassino, A., Karasawa, H., Schweigert, G., 2010, Systematic list of fossil decapod crustacean species: Crustaceana Monographs, 10, viii $+221 \mathrm{p}$.

Schweitzer, C.E., Feldmann, R.M., Karasawa, H., 2007b, Revision of the Carcineretidae Beurlen, 1930 (Decapoda: Brachyura: Portunoidea) and remarks on the Portunidae Rafinesque, 1815: Annals of Carnegie Museum, 76, 15-37.

Secrétan, S., 1961, Une nouvelle espèce de Xanthidés au Maroc: Titanocarcinus meridionalis nov. sp.: Notes de Service Géologique de Maroc, 20(152), 39-50.

Secrétan, S., 1964, Les Crustacés décapodes du Jurassique supérieur et du Crétacé de Madagascar: Mémoires du Muséum national d'Histoire naturelle, Nouvelle série, Série C, Sciences de la Terre 14: 1-226.

Spiridonov, V.A., Neretina, T. V., Schepetov, D., 2014, Morphological characterization and molecular phylogeny of Portunoidea Rafinesque, 1815 (Crustacea Brachyura): Implications for understanding evolution of swimming capacity and revision of the family-level classification: Zoologischer Anzeiger, 253, 404-429.

Stenzel, H.B., 1952, Decapod crustaceans from the Woodbine Formation of Texas, in Stephenson, L.W. (ed.), Larger invertebrate fossils of the Woodbine Formation (Cenomanian) of Texas. Geological Survey Professional Paper, 242, 212-217.

Stephenson, W., Campbell, B., 1960, The Australian portunids (Crustacea: Portunida) IV. Remaining genera: Australian Journal of Marine and Freshwater Research, 11(1), 73-122.

Števčić, Z., 2005, The reclassification of brachyuran crabs (Crustacea: Decapoda: Brachyura): Natura Croatica (Fauna Croatica), 14, suppl. 1, 1-159.

Téodori, D., Ossó, À., Nyborg, T., Vega, F., 2013, The Icriocarcinidae (Brachyura, Portunoidea), a widely distributed family during the latest Cretaceous times, in Krobicki, M. (ed.), 5th Symposium on Mesozoic and Cenozoic Decapod Crustaceans, 72. Kraków, Poland: Abstract Book. Polish Geological Institute, National Research Institute, Warszawa.

Van Straelen, V., 1924, Description de Brachyoures montiens du Cominges. Bulletin de la Société Belge de Géologie, 34, 58-62. 
Van Straelen, V., 1934, Contribution à l'étude des crustacés décapodes fossiles de la Catalogne: Géologie des Pays Catalans, 3(25), 1-6.

Van Straelen, V., 1936, Crustacés Décapodes nouveaux ou peu connus de l'époque crétacique: Bulletin du Musée royal d'Histoire naturelle de Belgique, 12(45), 1-50.

Van Straelen, V, 1937, Parapirimela angolensis, Brachyure nouveau du Miocène de l'Angola: Bulletin du Musée Royal d'Histoire Naturelle de Belgique, Bruxelles, 8(5), 1-4.

Vega, F. J., Bruce, N. L., Serrano, L., Bishop, G. A., Perrilliat, M. D. C., 2005, A review of the Lower Cretaceous (Tlayúa Formation: Albian) Crustacea from Tepexi de Rodríguez, Puebla, Central Mexico: Bulletin of the Mizunami Fossil Museum, 32, 25-30.

Vega, F.J., Feldmann, R.M., García-Barrera P., Filkorn H., Pimentel, F., Avendaño, J., 2001, Maastrichtian Crustacea (Brachyura: Decapoda) from the Ocozocuautla Formation in Chiapas, southeast Mexico: Journal of Paleontology, 75(2), 319-329.

Vega, F.J., Feldmann, R.M., Sour-Tovar, F., 1995, Fossil crabs (Crustacea: Decapoda) from the Late Cretaceous Cárdenas Formation, eastcentral Mexico: Journal of Paleontology, 69, 340-350.

Vega, F.J., Phillips, G.E., Nyborg, T., Flores-Ventura, J., Clements, D., Espinosa, B., Solís-Pichardo, G., 2013, Morphology and size variation of a portunoid crab from the Maastrichtian of the Americas: Journal of South American Earth Sciences, 47, 116-135.

Veiga Ferreira, O. da, 1957, Acerca de Parapirimela angolensis Van Straelen nas Camadas de Iela, Angola: Comunicações dos Serviços Geológicos de Portugal, XXXVIII, 465-468.

Vilas, L., Mas, R., García, A., Alonso, A., Meléndez, N., Rincón, R., 1982, Ibérica Suroccidental, in García, A. (Ed.), El Cretácico de España. Universidad Complutense de Madrid, Madrid, 457-513.

Withers, T.H., 1922, On a new brachyurous crustacean from the Upper Cretaceous of Jamaica: Annals and Magazine of Natural History, 9(10), 534-541.

Woodward, H., 1873, Further notes on Eocene Crustacea from Portsmouth: Quarterly Journal of the Geological Society of London, 29, 25-31.

Manuscript received: September 30, 2015

Corrected manuscript received: December 30, 2015

Manuscript accepted: January 10, 2016 